剝離骨折を併なった陳旧性後十字勒帯単独損傷に 対する一次的修復術の小経験

\author{
公立玉名中央病院整形外科 \\ 中 野 哲 雄 \\ 熊本中央病院整形外科 \\ 竹下雄二・前川清 継
}

\title{
Two Cases of Primary Repair of Chronic Posterior Cruciate Ligment Injury with Avulsion Fracture of the Tibia
}

by

\author{
T. Nakano \\ Department of Orthopedic Surgery Tamana Chuo \\ Hospital, Kumamoto \\ U. Takeshita and K. Maekawa \\ Kumamoto Central Hospital
}

Primary repair is possible, because usually Cruciate ligment shows atrophy in about two weeks after injury, but, Posterior Cruciate injury with avulsion fracture of the tibia does not show atrophy even after several months. Primary repair of chronic posterior crusiate ligment injury leads good results.

Case 1: 69 years old, male

The patient was injured during riding on a motorcycle. He had not recieved any surgical treatment for his knee. Two moths later, he complained of continuous knee pain. Posterior drawer sign was found on his knee. Avulsion fracture of the tibia was found in X-ray film. Primary repair was done in 75 days. After the operation, pain was releaved. Stability has been gained and R. O. M. is in the normal range. We rate the result excellent according to the Solonen's criteria.

Case 2: 57 years old, female

The patient was injured during riding on a motorcycle. She had not recieved any surgical treatment for her knee. Two months later, she complained of continuous knee pain. Posterior drawer sign was found on her knee. Avulsion fracture of the tibia was found in X-ray film. Primary repair was done in 117 days. After the operation, pain was releaved. Stability has been gained and R. O. M. is in the normal range.

We rate the results excellent according to the Solonen's criteria.

\section{はじめに}

後十字靯带紧独損伤は, 従来, 比校的稀な屯のと考 えられていたが，実際は見逃し例が多く，その発生頻 度はかなり高いと思われる，剝離骨折を作なうすの 之，併なわないあのとがあるが，永離骨折があれば， 信断は比較的容易である．剝離骨折を併なわない場 合，新鮮時には，無麻醁下での晾断は困難な場合があ
る. 又, 㔀離骨折を併なったものでさえ，交通外傷 等，他の外傷を併なった場合には見逃がされ，陳旧性 となったあのを, 散見することができる. 陳旧性の後 十字靶帯損傷患者は滕の不安全性を訴えることが多 い、しかし，䟝離骨折を併なった場合は疼痛を主訴と するようである，治療は，不安定感に対しては，大腿 四頭筇筋力增強訓練を行ない，良好な結果を得る。し かし, 剝離骨折がある場合は一次的修復術が可能であ 
り，こ机によって，疼痛のみならず，不安定性も消失 させるととが可能である. 今回我々は 2 例の陳旧性後 十字靶带単独損賃に刘し一次的修復術を行ない, 良い 絬果を得たので報告する.

考察

症例 1：69才 男性

バイク運転中 乘用車にはねられた。意識陾宫があ り，滕に対しては何ら治療走受けなかった。受伤2 ケ 月後, 㯟痛持続する為紹介された。路行痛，不安定感

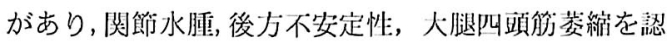

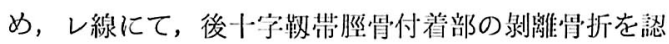
めた（戍 1 ）。受賃後 75 日で一次的修復術を行なっ

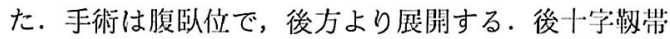
は骨片を例なって㔀離しており，周囲は搬痕で埋って いた，骨片の異常可動性が涩められ，後方不安定性が あった. 後十字跑带は, 肉眼的には变性吸収はされて おらず，正常に近い外観を呈していた．䩓帯に付着し ている骨片，及び，それと刘応する脛骨面を 新鮮化

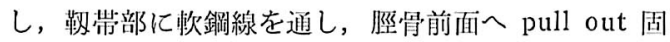
定した（図 2 ). 術後 37 日でギブス除去し, 滕装具を 装着した. 術後 100 日で, 屋内で装具を除去した。

現在，ROM は正常であり，不安定性はない。大腿 四頭伤萎縮は健側に比し， $0.5 \mathrm{~cm}$ 程度の差を認める

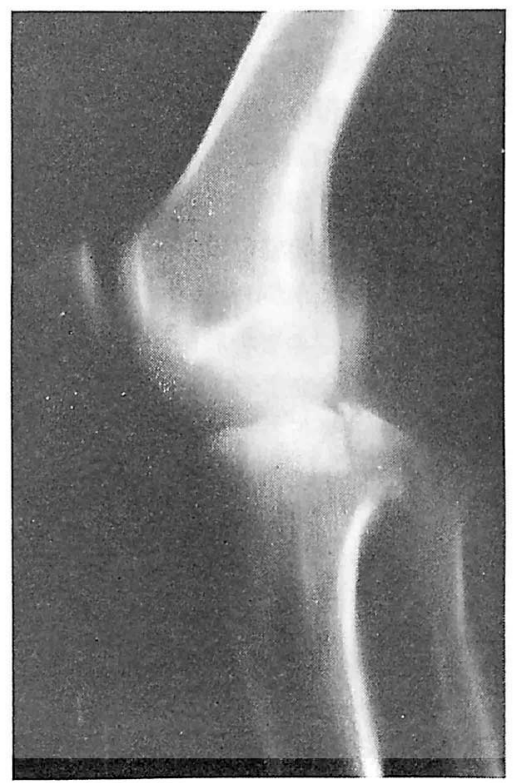

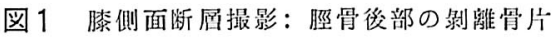
がわかる

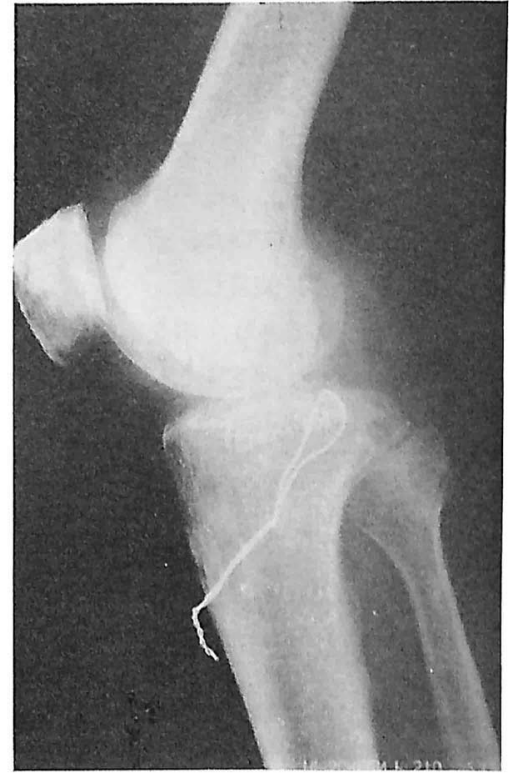

図 2 骨片梿酱復されている

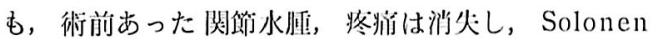
の判定基準で骖と判定した。

症例 $2: 57$ 女性

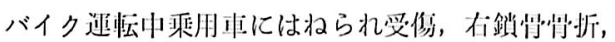
右㯟打掽で入院. 右滕に刘しては，何ら治将走受け

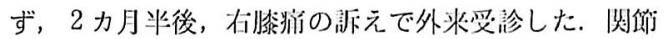

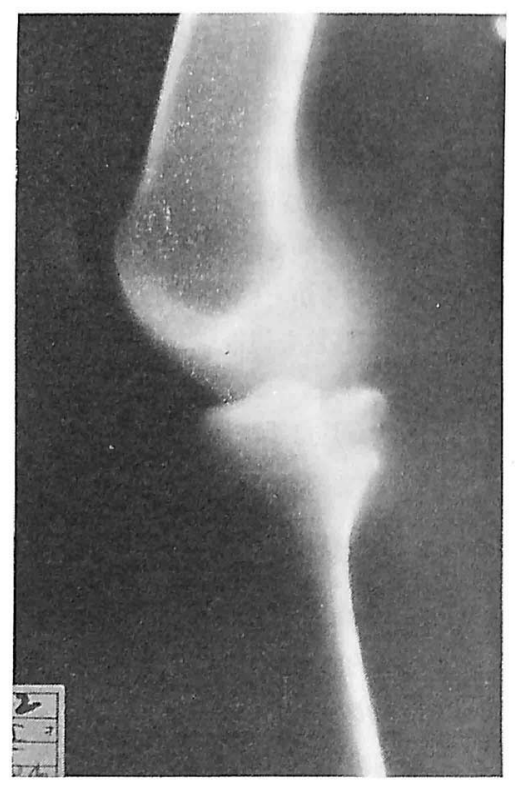

図 3 滕侧面断原据影 
血腫があり, 関節の不安定感, 後方不安定性, 歩行痛 が認められ，上線像にて，後十字㗆带巠付着部の䟝離 骨折を認めた（図 3 ). 受伤後 117 月で一次的修復術 を行なった。症例 1 と同じく, 粎鋼線にて pull out 固定を行なった. 術中所見は症例 1 とほぼ同様で, 後 十字鞄帯は変性せず残っていた. 術後 5 週間ギブス固 定を行ない, 以後䐐装具装着した。

現在, ROM は正常であり, 不安定性はなく関節水 腫, 疼痛も消失した. 大腿四頭筋萎縮 あ腱倒に比し $0.5 \mathrm{~mm}$ 程度である. Solonen の判定基集で骖と判 定した.

$$
\text { 考察 }
$$

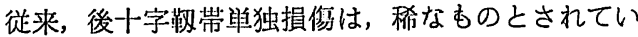
た。しかし，Tricky やSmillie はとの損傷は見逃 し例が多いと指摘している. 本邦であ, 今井, 鳥巣, 杉浦らによって，乙の損傷が稀なものではなく，しば しば経験する損伤だとの報告がなされた，新鮮例の治 療は, 保存療法, 観血療法共に良㶩な結果を得ること が多い，陳旧例に対する治療は，大腿四頭筋の觔力增 強訓練を中心とした保存療法が行なわれるととが多 い. 不安定性はなくならないものの, 不安定感が改善 し，患者の愁訴はなくなることが多く，歎帯再腱術の 問題点を考えると，保存療法が選択されるととが多い のは当然であ万う。しかし，影離骨折を併なった後十 字鞄带損傷は，疼痛を主訴とするととが多い。乙の疼 痛の一因として，剥離骨片の異常可動性が考えられ， てのような場合には手術療法が必要であろう，又，乙 のような場合，後十字䩓带は血行が温存されていると 思わ机，萎縮・変性等の所見は肉眼的には軽微であ り，一次的修復術が可能である．さて受傷後いつまで 一次修復が可能であるかという問題であるが，鳥巣は 受㩯後 30 年の手術経験を報告している，我々の症例 は，受傷後 2 力月半と， 4 力月目に手術を行なった が，少なくとあ数力月は手術は容易に行なえるあのと 思わ机る。

$$
\text { ま と め }
$$

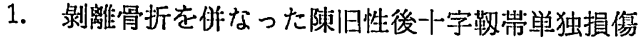
の 2 例に対し一次的修復術を行なった。

2. 本損筥は不安定感のみならず，疼痛を訴えるこ とが多く, 観血的治療の対象之なることが多い.

3. 通常十字鞄帯は受鹪後早期に変性菱縮をおこす
が，てのような場合は正常に近い状態で温存されてい る.

4. 一次的修復術を容易に行うことが出来る

5. 我々が経験した 2 例は Solonen の判定基準で いずれも優の成績をおさめた。

\section{参 考 文 献}

1）今井 望：㷜関節軟部支持構損㑺の治療。日整 会誌, 50: 1077-1089, 1976.

2）今井立史：䟝雖骨折を伴なった新㙰後十字勒帯 学独提傝汇ついて。整形災害外科，22：817-827， 1967.

3) Smillie, I. S.: Injuries of the knee joint, fourth edition, Edinburgh London \& New York; E. \& S. Livingstone Ltd., 1970.

4) Solonen, K. A. et al.: Operative treatment of torn ligaments in injuries of the knee joint, Acta Orthop. Scand., 38: 67 80, 1967.

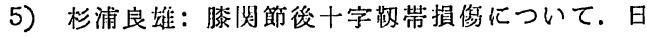
整会琹，47：422-423，1973.

6) Trickey, E. L.: Rupture of the posterior cruciate ligament of the knee, J. Bone Joint Surg., 50-B: 334-341, 1968.

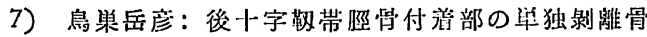
折について。臨整外, 12: 757-764, 1977.

\section{質 問 九州学災病院 州原 秀俊}

私自身む陳旧性 PCL 脛骨付着部剝離骨折を 4 例 ぞ経験したが，団:床へ骨片に整後する際，ひき下げる のがかなり困難で靱帯の萎縮があったように考える. PCL の場合，主な血行は圧骨側より供給される之さ れるが，先生の例では靱带は菱縮しておらず正常だっ たといわれたので，その場合の血行は滑膜などからき ていたとお考えでしようか．或いは関節後から筷拻さ れていたとの考えでしようか.

解 答公立玉名印央病院 中野 哲雄

(1) 涇骨側の剝離骨折を伴なった後十字鞄帯損傷は 自験例では，搬痕の中に骨片が埋って扝り，搬痕を通 し血行が存在し，鞄带が菱縮しないのではないかと考 えた。

\section{質 問 長崎大学 乗松 敏啨}

陳旧性のはくり骨折の場合，骨瘉合の判定が困難で すが，どのように判定していますか

解 答公立玉名中央病院 中野 哲雄

(2) Pull out した wire の抜釬侍期は可及的に長 期間固定している。 